\title{
PENGARUH HARGA, PROMOSI DAN KUALITAS PELAYANAN TERHADAP BRAND IMAGE GRAB DENGAN KEPUASAN KONSUMEN
}

\author{
Ida Bagus Putra Pradnyana1 \\ I Gusti Ngurah Putra Suryanata 2
}

1,2 Magister Manajemen, Universitas Pendidikan Nasional, Denpasar, Indonesia

1email: ibputrapradnyana@gmail.com

²email :ngurahputrasuryanata@undiknas.ac.id

\begin{abstract}
ABSTRAK
Tujuan penelitian ini adalah untuk mengetahui pengaruh harga, promosi dan kualitas pelayanan dan kepuasan konsumen pada brand image. Populasi dalam penelitian ini adalah masyarakat di Kota Denpasar yang menggunakan aplikasi Grab. Jumlah sampel yang didapat adalah 100 responden dengan menggunakan rumus Lemeshow, yang telah ditentukan dengan metode non probability sampling yaitu sampling incidental. Teknik analisis yang digunakan adalah metode statistik Structural Equation Model (SEM). Hasil pengujian menunjukkan bahwa variabel harga, promosi, kualitas pelayanan dan kepuasan konsumen berpengaruh pada brand image.
\end{abstract}

Kata kunci: harga, promosi, kualitas pelayanan, kepuasan konsumen, brand image

\begin{abstract}
The purpose of this study was to determine the effect of price, promotion and service quality and customer satisfaction on brand image. The population in this study are people in Denpasar City who use the Grab application. The number of samples obtained is 100 respondents using the Lemeshow formula, which has been determined by the non-probability sampling method, namely incidental sampling. The analysis technique used is the statistical method of Structural Equation Model (SEM). The test results show that the variables of price, promotion, service quality and customer satisfaction have an effect on brand image.
\end{abstract}

Keywords: price, promotion, service quality, customer satisfaction, brand image 


\section{PENDAHULUAN}

Transportasi online merupakan jasa transportasi yang berbasis internet. Semakin berkembangnya Jaman, kini transportasi online dapat dengan mudah diakses menggunakan aplikasi yang ada didalam smartphone. Didalam aplikasi tersebut, pelanggan sudah dapat mengetahui identitas dari ojek yang dipesan, berapa jarak tempuh dan tarif yang di bebankan kepada pengguna. Kemudahan tersebut terjadi akibat perkembangan jaman yang begitu cepat.

Jasa transportasi online yang semakin berkembang bukan lagi menjadi hal yang buruk namun lebih memudahkan masyarakat dalam menjangkau berbagai hal serta sistem yang dibuat lebih transparan dan tepat sasaran atas kecenderungan pemakaian modal dengan skala kecil melalui pertimbangan uatam seperti faktor waktu perjalanan, kertersediaan, dan fleksibilitas dalam perjalanan. Masyarakat bisa dengan mudah memesan melalui aplikasi tanpa harus menunggu lama untuk mengambil barang. Setidaknya kemacetan lalu lintas bisa diatasi dengan transportasi online roda dua atau biasa disebut ojek online.

Salah satu perusahaan transportasi online yang hadir untuk mengatasi permasalahan tersebut adalah Grab. Grab merupakan salah satu aplikasi super terkemuka di Asia Tenggara, yang menyediakan solusi harian termasuk layanan transportasi, pengiriman makanan dan kargo, pembayaran seluler, dan hiburan digital (Cahyu, 2019). Dengan konsep platform terbuka, Grab telah mengumpulkan mitra untuk meningkatkan taraf hidup seluruh pengguna di Asia Tenggara. Pada tahun 2016 dan 2017 Brand Grab menduduki posisi kedua dikalahkan oleh Gojek diposisi pertama. Pada tahun 2018 Brand Grab menduduki posisi pertama mengalahkan Gojek, namun pada tahun 2019 Brand Grab kembali turun menduduki posisi kedua dikalahkan kembali oleh Gojek. Sejauh ini Grab berusaha menjangkau masyarakat banyak melalui promosi pada iklan dengan menggunakan media seperti media sosial maupun melalui aplikasi dari Grab sendiri. Promosi yang biasanya dilakukan oleh Grab adalah potongan harga dengan cara menukarkan kode promo untuk mendapatkan potongan harga tersebut. (Kasmir, 2016) mengatakan promosi merupakan sarana yang paling ampuh untuk menarik dan mempertahankan nasabahnya. Sedangkan (Assauri, 2014) menjelaskan bahwa promosi adalah kegiatan yang dilakukan untuk mempengaruhi nasabah untuk menciptakan permintaan atas suatu produk atau jasa. (Kotler \& Amstrong, 2012) mengemukakan bahwa ada lima alat promosi utama: periklanan, promosi, hubungan masyarakat, penjualan pribadi, dan penjualan langsung. Menurut (Simanjuntak \& Ardani, 2018) mendapatkan hasil bahwa promosi memiliki pengaruh yang positif dan signifikan terhadap brand image jasa transportasi Uber Taksi di Kota Denpasar.

Selain memberikan promosi, tarif juga menentukan adanya brand image yang baik. (Kotler \& Amstrong, 2012) mengemukakan bahwa harga merupakan suatu jumlah yang dibebankan untuk suatu produk atau layanan, atau jumlah nilai yang ditukar konsumen untuk memiliki atau menggunakan produk atau layanan tersebut. Dari hasil pencarian dalam data sekunder Grab, harga Grab Car per kilometer adalah Rp7.000 dan Grab Bike Rp2.650, dan untuk Grab Food Rp3.000 pada tahun 2020, di luar jam sibuk. Namun jika volume pesanan tinggi atau pengguna aplikasi Grab sedang ramai menggunakan aplikasi dan jika cuaca sedang hujan sehingga 
driver grab sedikit yang bekerja, maka harga dapat naik dengan sendirinya dan pengguna akan sedikit lebih lama dalam menunggu pesanannya sehingga mempengaruhi citra merek yang dimiliki oleh Grab. Inti dari penentuan harga adalah mempertahankan harga dengan tepat ditentukan oleh penjual sehingga pelanggan tidak dirugikan dan kecewa, sehingga berjuang strategi penetapan harga memiliki tujuan sebagai komunikasi dimaksudkan untuk pembeli atau pelanggan menciptakan hubungan yang sadar tetapi tidak mengikat mereka (Luo \& Chung, 2015). Menurut (Simanjuntak \& Ardani, 2018) mendapatkan hasil bahwa promosi memiliki pengaruh yang positif dan signifikan terhadap brand image jasa transportasi Uber Taksi di Kota Denpasar. Hasil penelitian dari (Anggriana, 2017) menyatakan bahwa harga mempunyai pengaruh positif signifikan terhadap kepuasan pelanggan jasa ojek online "Om-Jek" Jember.

Kualitas layanan merupakan suatu tingkat keunggulan yang diinginkan dan menjadi pengendalian tingkat keunggulan ini dalam rangka memenuhi kebutuhan pelanggan (Tjiptono \& Gregorius, 2016). Kotler dalam (Tjiptono \& Gregorius, 2016) mengungkapkan jika terdapat lda lima faktor utama atau penentu kualitas layanan, lima faktor utama tersebut antara lain: tangibility, empathy, responsiveness, reliability dan assurance. Kualitas pelayanan yang diberikan juga penting dalam menentukan brand image yang baik dari Grab karena menurut (Sari, 2019) kualitas layanan berpengaruh positif dan signifikan terhadap citra merek. Kualitas dari pelayanan Grab tergantung dari driver itu sendiri. Apabila driver dari grab tersebut melayani konsumennya dengan ramah maka akan memunculkan kepuasan yang baik bagi konsumen sehingga menimbulkan brand image yang baik bagi Grab, begitu pula sebaliknya apabila driver grab melayani konsumen dengan kurang ramah maka kepuasan konsumen akan kurang sehingga menimbulkan brand image yang buruk bagi Grab. Menurut (Putri, A. K, Hendrayani \& Uljanatunnisa, 2020) terdapat pengaruh yang signifikan antara kualiatas pelayanan terhadap citra perusahaan Ninja Xpress.

Dalam persaingan berbagai perusahaan dalam memasarkan maupun menjual produknya, berbagai cara pastinya dilakukan untuk memperoleh pelanggan dan mempertahankannya. Salah satu strategi yang dipakai perusahaan untuk bisa memenangkan persaingan adalah dengan kualitas layanan yang baik. Dengan perusahaan memberikan pelayanan yang baik, maka pelanggan akan tertarik membeli sebuah produk atau jasa karena kualitas pelayanannya yang baik. Menurut Choudhury dalam (Christina \& Fransisca, 2014) mengatakan untuk dapat bersaing dengan kompetitornya, sebuah perusahaan harus memiliki ciri khas yang menjadi penentu keberhasilan yaitu dengan menyediakan layanan berkualitas tinggi. Jika pelayanan yang diterima konsumen buruk, maka akan menyebabkan ketidakpuasan pada konsumen.

(Kotler \& Kevin, 2016) menjelaskan bahwa brand Image adalah persepsi konsumen tentang suatu merek sebagai refleksi dari asosiasi yang ada pada pikiran konsumen. Sedangkan (Tjiptono, 2014) mengemukakan bahwa citra merek adalah deskripsi asosiasi dan keyakinan konsumen terhadap merek tertentu. Apabila didasarkan pada pengalaman dan mendapatkan banyak informasi, maka hubungan antara sebuah merek dan produk yang dijual akan semakin erat. Citra merek atau asosiasi menunjukkan persepsi yang mungkin atau mungkin tidak mencerminkan 
realitas objektif. Citra yang dibentuk oleh asosiasi (persepsi) menjadi dasar keputusan pembelian bahkan loyalitas merek konsumen.

(Sunyoto, 2014) menjelaskan bahwa kepuasan konsumen mengacu pada tingkat persepsi (kinerja atau hasil) seseorang dibandingkan dengan harapan. Sedangkan (Sangadji \& Sopiah 2013) menjelaskan bahwa kepuasan pelanggan diartikan sebagai situasi dimana harapan konsumen terhadap produk sesuai dengan kenyataan yang diterima konsumen. Ketika konsumen sangat puas dengan produk atau jasa yang diberikan oleh perusahaan, maka mereka dapat melihat kesuksesan perusahaan. Tujuan dari penelitian ini adalah untuk mengetahui pengaruh harga, promosi dan kualitas pelayanan, dan kepuasan konsumen terhadap citra merek.

Hipotesis yang dikemukakan dalam penelitian ini adalah :

$\mathrm{H}_{1}$ : Semakin sesuai harga maka semakin baik brand image perusahaan Grab

$\mathrm{H}_{2}$ : Semakin baik promosi maka semakin baik brand image perusahaan Grab

$\mathrm{H}_{3}$ : Semakin baik kualitas pelayanan maka semakin baik brand image perusahaan Grab

$\mathrm{H}_{4}$ : Semakin sesuai harga maka semakin baik kepuasan konsumen pengguna Grab

$\mathrm{H}_{5}$ : Semakin baik pormosi maka semakin baik kepuasan konsumen pengguna Grab

$\mathrm{H}_{6}$ : Semakin baik kualitas pelayanan maka semakin baik kepuasan konsumen pengguna Grab

$\mathrm{H}_{7}$ : Semakin baik kepuasan kosnumen maka semakin baik brand image pengguna Grab

Hipotesis tersebut jika digambarkan dalam sebuah bagan menjadi seperti berikut.

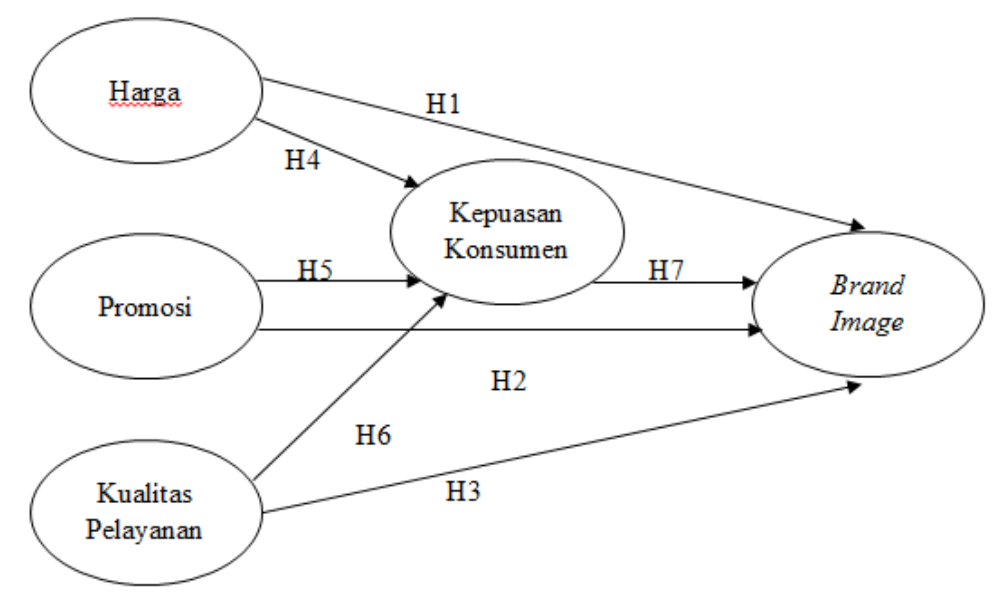

Gambar 1. Model Hubungan Antar Variabel

\section{METODE PENELITIAN}

Lokasi penelitian dilakukan di Kota Denpasar. Peneliti memilih lokasi ini karena tertarik untuk mengetahui bagaimana respon dari masyarakat di Kota Denpasar mengenai adanya Grab yang saat ini menjadi alternatif lain bagi 
masyarakat yang tidak ada waktu untuk keluar rumah untuk membeli makanan ataupun tidak adanya transportasi dari masyarakat untuk bekerja. Dalam penelitian ini yang menjadi populasi adalah seluruh masyarakat di Kota Denpasar yang menggunakan aplikasi Grab. Teknik pengambilan sampel yang digunakan dalam penelitian ini adalah Teknik non probability sampling yaitu teknik sampling incidental. Jumlah sampel yang diambil dalam penelitian ini menggunakan rumus Lemeshow.

Teknik pengumpulan data dalam penelitian ini adalah : kuesioner, studi pustaka, dan internet. Untuk menjawab permasalahan dan menguji hipotesis pengaruh harga, promosi dan kualitas pelayanan terhadap brand image dengan kepuasan konsumen sebagai variabel intervening, digunakan metode statistik Structural Equation Model (SEM) yang dibantu dengan program SPSS 16.00 dan $A M O S$ 2. SEM menggunakan pendekatan konfirmasi yang memiliki aspek penting yaitu: suatu proses penelitian ditampilkan dalam bentuk persamaan struktural (regresi) dan korelasi struktural dari persamaan tersebut, yang dapat ditampilkan secara intuitif, sehingga teori konseptual dapat dipelajari dengan lebih mudah.. Digunakannya metode $S E M$ dalam penelitian ini, karena $S E M$ memungkinkan dapat menjawab pertanyaan penelitian yang bersifat regresif maupun dimensional, yaitu dapat mengukur dimensi dimensi dari sebuah konsep.

Langkah-langkah yang dilakukan dalam analisis ini adalah: (1) evaluasi terhadap normalitas data, (2) pengujian analisis faktor konfirmatori (CFA) dan (3) analisis Pengaruh dengan SEM. Selanjutnya dilakukan analisis model struktural, analisis goodness of fit, analisis determinasi, analisis model pengukuran dengan parameter lamda untuk pengaruh harga, promosi dan kualitas pelayanan terhadap brand image dengan kepuasan konsumen sebagai variabel intervening. Persamaan harga, promosi dan kualitas pelayanan terhadap brand image dengan kepuasan konsumen seperti persamaan berikut:

$$
\begin{array}{lll}
\mathrm{Y}=y_{1} \mathrm{X}_{1}+\xi_{1}, & \longrightarrow & \text { pengaruh } \mathrm{X}_{1} \text { terhadap } \mathrm{Y} \\
\mathrm{Y}=\mathrm{y}_{2} \mathrm{X}_{2}+\xi_{1}, & \longrightarrow & \text { pengaruh } \mathrm{X} 2 \text { terhadap } \mathrm{Y} \\
\mathrm{Y}=\mathrm{y}_{3} \mathrm{X}_{3}+\xi_{1}, & \longrightarrow & \text { pengaruh } \mathrm{X}_{3} \text { terhadap } \mathrm{Y} \\
\mathrm{Y}=\mathrm{y}_{1} \mathrm{X}_{1}+\xi_{2} & \longrightarrow & \text { pengaruh } \mathrm{X}_{1} \text { terhadap } \mathrm{Z} \\
\mathrm{Y}=\mathrm{y}_{2} \mathrm{X}_{2}+\xi_{2} & \longrightarrow & \text { pengaruh } \mathrm{X}_{2} \text { terhadap } \mathrm{Z} \\
\mathrm{Y}=\mathrm{y}_{3} \mathrm{X}_{3}+\xi_{2} \longrightarrow & \text { pengaruh } \mathrm{X}_{3} \text { terhadap } \mathrm{Z} \\
\mathrm{Y}=\mathrm{ZY}+\xi_{1} \longrightarrow & \text { pengaruh } \mathrm{Z} \text { terhadap } \mathrm{Y}
\end{array}
$$

Pengujian model dilakukan menggunakan koefisien regresi untuk variabel harga $\left(\mathrm{X}_{1}\right)$, promosi $\left(\mathrm{X}_{2}\right)$, kualitas pelayanan $\left(\mathrm{X}_{3}\right)$, brand image $(\mathrm{Y})$, kepuasan konsumen (Z) melalui tabel output dari sub menu view/set.

Analisis model pengukuran dengan determinasi digunakan untuk mengetahui besarnya sumbangan variabel harga, promosi dan kualitas pelayanan terhadap brand image dengan kepuasan konsumen. Modifikasi model dilakukan untuk meningkatkan nilai Chi-square, yaitu dengan mengkorelasikan error berapa indikator ataupun mengkorelasikan beberapa indikator nilai modifikasi indeks yang besar.

Analisis model Pengukuran dengan determinasi digunakan untuk mengetahui besarnya sumbangan variabel harga, promosi dan kualitas pelayanan terhadap brand image dengan kepuasan konsumen. Menurut Ferdinand (2012), bahwa nilai 
Square Multiple Correlation identik dengan R pada SPSS. Determinasi $=$ Square Multiple Correlation X 100\%.

Modifikasi model dilakukan untuk meningkatkan nilai Chi-square, yaitu dengan mengkorelasikan error berapa indikator ataupun mengkorelasikan beberapa indikator nilai modifikasi indeks yang besar. Untuk itu dilakukan modifikasi model dengan mengkombinasikan beberapa error yang memiliki koefisien modifikasi indeks $>10,000$ dengan harapan dapat membesarkan nilai Chi-square. Modifikasi dilakukan untuk mendapatkan model yang baik dengan jalan yang menghilangkan atau tidak menyertakan indikator yang memiliki standardized regression weight paling kecil.

\section{HASIL DAN PEMBAHASAN}

Penelitian harga, promosi, kualitas pelayanan, brand image dan kepuasan konsumen dilakukan bukan untuk menghasilkan sebuah model, tetapi ditujukan untuk untuk mengkonfirmasi model hipotesis melalui data empiris. Setiap responden diminta untuk menjawab kuesioner yang telah diuji validitas dan reliabilitasnya berkaitan dengan harga, kualitas pelayanan, brand image dan kepuasan konsumen. Variabel harga memuat 5 pertanyaan, variable promosi memuat 4 pertanyaan, variable kualitas pelayanan memuat 5 pertanyaan, variable brand image memuat 3 pertanyaan, variable kepuasan konsumen memuat 3 pertanyaan.

Evaluasi normalitas dilakukan dengan uji skewness dan kurtosis. Uji skewness digunakan untuk melihat kemencengan atau kecondongan penyebaran data, Sedangkan kurtosis untuk melihat keruncingan penyebaran data. Uji normalitas dilakukan untuk data setiap variabel laten, yaitu data variabel harga, promosi, kualitas pelayanan, brand image dan kepuasan konsumen. Berdasarkan hasil pengolahan data penelitian komputer Amos for Windows versi 24 untuk masing-masing variabel laten, hasil yang diperoleh dari pengolahan evaluasi normalitas Amos versi Windows 24 yaitu hasil yang diperoleh dari kelima indikator variabel harga tersebut dapat diketahui bahwa Skweness tidak ada indikator yang lebih besar dari $\pm 3,00$. Artinya, distribusi data harga normal dalam hal kemiringan. Dari perspektif kurtosis (taper), tidak ada indeks dengan nilai c.r lebih besar dari \pm 3,00. Bila dilihat dari kurtosis (keruncingan) dapat dikatakan bahwa penyebaran data untuk semua indikator adalah normal. Dengan demikian berarti ditinjau dari normalitas, semua indikator memunihi syarat. Untuk analisis selanjutnya, variabel laten harga diwakili oleh 5 indikator.

Tabel 1.

Uji Normalitas Variabel Harga

\begin{tabular}{lrrrrrr}
\hline Variable & min & max & skew & c.r. & kurtosis & c.r. \\
\hline HG1 & 1.000 & 5.000 & -.645 & -2.632 & .025 & .051 \\
HG2 & 1.000 & 5.000 & -.676 & -2.762 & -.290 & -.591 \\
HG3 & 1.000 & 5.000 & -.641 & -2.615 & .116 & .237 \\
HG4 & 1.000 & 5.000 & -.717 & -2.928 & -.041 & -.084 \\
\hline
\end{tabular}

Bersambung... 
Lanjutan Tabel 1.

\begin{tabular}{lrrrrrr} 
Variable & min & max & skew & c.r. & kurtosis & c.r. \\
\hline HG5 & 1.000 & 5.000 & -.594 & -2.426 & -.038 & -.078 \\
Multivariate & & & & & 3.032 & 1.812 \\
\hline Sumber: Data Penelitian, 2020 & & & & &
\end{tabular}

Hasil selanjutnya yaitu, dari 4 indikator variabel promosi dapat diketahui bahwa tidak ada indikator yang memiliki c.r untuk skweness lebih besar dari $\pm 3,00$. Ini berarti sebaran data promosi adalah normal ditinjau dari kemencengan. Dilihat dari kurtosis (keruncingan), tidak ada indikator memiliki nilai c.r lebih besar dari \pm 3,00. Ini berarti, bila dilihat dari kurtosis (keruncingan) dapat dikatakan bahwa penyebaran data untuk semua indikator adalah normal. Dengan demikian berarti ditinjau dari normalitas, semua indikator memunihi syarat. Untuk analisis selanjutnya, variabel laten promosi diwakili oleh 4 indikator.

Tabel 2.

Uji Normalitas Variabel Promosi

\begin{tabular}{lrrrrrr}
\hline Variable & min & max & skew & c.r. & kurtosis & c.r. \\
\hline PRO1 & 1.000 & 5.000 & -.711 & -2.903 & .389 & .794 \\
PRO2 & 1.000 & 5.000 & -.675 & -2.756 & .313 & .638 \\
PRO3 & 1.000 & 5.000 & -.507 & -2.069 & .052 & .106 \\
PRO4 & 1.000 & 5.000 & -.690 & -2.815 & .215 & .440 \\
Multivariate & & & & & 1.487 & 1.073 \\
\hline
\end{tabular}

Sumber: Data Penelitian, 2020

Hasil pengujian 5 indikator variabel kualitas pelayanan dapat diketahui bahwa tidak ada indikator yang memiliki c.r untuk skweness lebih besar dari $\pm 3,00$. Ini berarti sebaran data kualitas pelayanan adalah normal ditinjau dari kemencengan. Dilihat dari kurtosis (keruncingan), tidak ada indikator memiliki nilai c.r lebih besar dari $\pm 3,00$. Ini berarti, bila dilihat dari kurtosis (keruncingan) dapat dikatakan bahwa penyebaran data untuk semua indikator adalah normal. Dengan demikian berarti ditinjau dari normalitas, semua indikator memunihi syarat. Untuk analisis selanjutnya, variabel laten kualitas pelayanan diwakili oleh 5 indikator.

Tabel 3.

Uji Normalitas Variabel Kualitas Layanan

\begin{tabular}{lrrrrrr}
\hline Variable & min & max & skew & c.r. & kurtosis & c.r. \\
\hline KP1 & 2.000 & 5.000 & -.234 & -.956 & -.656 & -1.340 \\
KP2 & 1.000 & 5.000 & -.343 & -1.402 & -.322 & -.656 \\
KP3 & 1.000 & 5.000 & -.674 & -2.751 & .182 & .372 \\
KP4 & 1.000 & 5.000 & -.303 & -1.239 & -.677 & -1.382 \\
KP5 & 1.000 & 5.000 & -.265 & -1.082 & -.385 & -.785 \\
Multivariate & & & & & 3.615 & 2.161 \\
\hline
\end{tabular}

Sumber: Data Penelitian, 2020

Pengujian dari 3 indikator variabel kepuasan konsumen dapat diketahui bahwa tidak ada indikator yang memiliki c.r untuk skweness lebih besar dari $\pm 3,00$. 
Ini berarti sebaran data kepuasan konsumen adalah normal ditinjau dari kemencengan. Dilihat dari kurtosis (keruncingan), tidak ada indikator memiliki nilai c.r lebih besar dari $\pm 3,00$. Ini berarti, bila dilihat dari kurtosis (keruncingan) dapat dikatakan bahwa penyebaran data untuk semua indikator adalah normal. Dengan demikian berarti ditinjau dari normalitas, semua indikator memunihi syarat. Untuk analisis selanjutnya, variabel laten kepuasan konsumen diwakili oleh 3 indikator.

Tabel 4.

Uji Normalitas Variabel Kepuasan Konsumen

\begin{tabular}{lrrrrrr}
\hline Variable & $\min$ & $\max$ & skew & c.r. & kurtosis & c.r. \\
\hline KK3 & 1.000 & 5.000 & -.704 & -2.875 & -.109 & -.222 \\
KK2 & 1.000 & 5.000 & -.672 & -2.745 & .006 & .012 \\
KK1 & 1.000 & 5.000 & -.665 & -2.716 & -.045 & -.092 \\
Multivariate & & & & & 2.981 & 2.722 \\
\hline Sumber: Data Penelitian, 2020 & & & & &
\end{tabular}

Uji normalitas untuk 3 indikator variabel brand image dapat diketahui bahwa tidak ada indikator yang memiliki c.r untuk skweness lebih besar dari $\pm 3,00$. Ini berarti sebaran data adalah normal ditinjau dari kemencengan. Dilihat dari kurtosis (keruncingan), tidak ada indikator memiliki nilai c.r lebih besar dari $\pm 3,00$. Ini berarti, bila dilihat dari kurtosis (keruncingan) dapat dikatakan bahwa penyebaran data untuk semua indikator adalah normal. Dengan demikian berarti ditinjau dari normalitas, semua indikator memunihi syarat. Untuk analisis selanjutnya, variabel laten brand image diwakili oleh 3 indikator. Dengan terpenuhinya normalitas semua sebaran data untuk setiap variabel, maka uji parametrik berupa analisis faktor konfirmatori (CFA) dapat dilakukan.

Tabel 5.

Uji Normalitas Variabel Brand Image

\begin{tabular}{lrrrrrr}
\hline Variable & $\min$ & $\max$ & skew & c.r. & kurtosis & c.r. \\
\hline BI3 & 1.000 & 5.000 & -.706 & -2.881 & .369 & .754 \\
BI2 & 1.000 & 5.000 & -.579 & -2.363 & -.186 & -.380 \\
BI1 & 1.000 & 5.000 & -.581 & -2.372 & -.067 & -.136 \\
Multivariate & & & & & 1.510 & 1.379 \\
\hline
\end{tabular}

Sumber: Data Penelitian, 2020

Analisis faktor konfirmatori digunakan untuk menguji unidimensionalitas dari dimensi-dimensi yang menjelaskan variabel laten dari model tersebut, apakah seluruh indikator yang dipakai dalam penelitian merupakan pembentuk variabel laten harga, promosi, kualitas pelayanan, brand image dan kepuasan konsumen. Analisis faktor konfirmatori ini juga dimaksudkan untuk menganalisis tingkat validitas dari data yang ada dalam penelitian. 


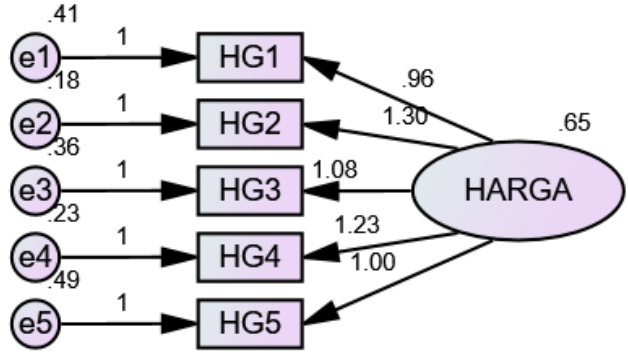

GOODNESS OF FIT MODEL

Prob=.928; Chisquare=1.365; CMIN/DF=.273

$\mathrm{RMR}=.013 ; \mathrm{NFI}=.996 ; \mathrm{CFI}=1.000, \mathrm{TLI}=1.020$

$\mathrm{IFI}=1.010 ; \mathrm{RFI}=.993 ; \mathrm{GFI}=.994$

AGFI=.983; RMSEA $=.000$

Gambar 2. Analisis Faktor Konfirmatori Variabel Harga

Sumber: Hasil Analisis Peneliti, 2020

Tabel 6.

Analisis Faktir Konfirmatori Variabel Harga

Regression Weights: (Group number 1 - Default model)

\begin{tabular}{|c|c|c|c|c|c|c|c|}
\hline & & & Estimate & S.E. & C.R. & $\mathbf{P}$ & Label \\
\hline$\overline{\text { HG5 }}$ & $<<--$ & HG & 1.000 & & & & \\
\hline HG4 & $<---$ & HG & 1.234 & .129 & 9.579 & $* * *$ & par_1 \\
\hline HG3 & $<---$ & HG & 1.079 & .125 & 8.614 & $* * *$ & par_2 \\
\hline HG2 & $<---$ & HG & 1.298 & .131 & 9.894 & $* * *$ & par 3 \\
\hline HG1 & $<---$ & $\mathrm{HG}$ & .956 & .119 & 8.022 & $* * *$ & par_4 \\
\hline
\end{tabular}

Tabel 7.

Squared Multiple Correlations: (Group number 1 - Default model) Variabel Harga

\begin{tabular}{lc|}
\hline & Estimate \\
\hline HG1 & .592 \\
HG2 & .858 \\
HG3 & .678 \\
HG4 & .811 \\
HG5 & .572 \\
\hline
\end{tabular}

Sumber: Data Penelitian, 2020

Berdasarkan tampilan analisis faktor konfirmatori terhadap indikator variabel harga, baik dalam bentuk diagram maupun dalam bentuk tabel diatas, diketahui bahwa Standardized Estimate Regression Weight $(\lambda)$ untuk semua indikator harga adalah lebih besar dari 0,50 dan C.R lebih besar dari 2,00 serta nilai probabilitas ke-5 indikator tersebut lebih kecil dari 0,05 (***). Dengan demikian dapat dikatakan ditinjau dari CFA, bahwa ke-5 indikator tersebut valid sebagai indikator yang membentuk variabel laten harga. 


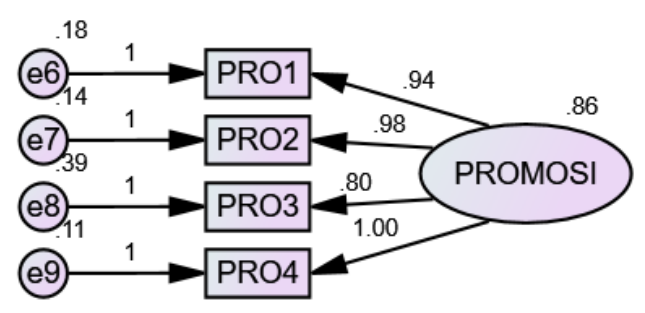

GOODNESS OF FIT MODEL

Prob=.465; Chisquare $=1.532 ; \mathrm{CMIN} / \mathrm{DF}=.766$

RMR $=.009 ; \mathrm{NFI}=.996 ; \mathrm{CFI}=1.000, \mathrm{TLI}=1.004$

IFI=1.001; RFI=.987; GFI=.992

AGFI=.960; RMSEA $=.000$

Gambar 3. Analisis Faktor Konfirmatori Variabel Promosi

Sumber: Hasil Analisis Peneliti, 2020

Tabel 8.

Variabel Promosi

Regression Weights: (Group number 1 - Default model)

\begin{tabular}{lllrrrrl}
\hline & & & Estimate & S.E. & C.R. & P & Label \\
\hline PRO4 & $<--$ & PRO & 1.000 & & & & \\
PRO3 & $<---$ & PRO & .798 & .077 & 10.394 & $* * *$ & par_1 \\
PRO2 & $<--$ & PRO & .982 & .059 & 16.742 & $* * *$ & par_2 \\
PRO1 & $<---$ & PRO & .943 & .060 & 15.749 & $* * *$ & par_3 \\
\hline
\end{tabular}

Sumber: Data Penelitian, 2020

Tabel 9.

Squared Multiple Correlations: (Group number 1 - Default model) Variabel Promosi

\begin{tabular}{lc}
\hline & Estimate \\
\hline PRO1 & .811 \\
PRO2 & .851 \\
PRO3 & .583 \\
PRO4 & .891 \\
\hline
\end{tabular}

Sumber: Data Penelitian, 2020.

Berdasarkan tampilan analisis faktor konfirmatori terhadap indikator variabel promosi, baik dalam bentuk diagram maupun dalam bentuk tabel diatas, diketahui bahwa Standardized Estimate Regression Weight $(\lambda)$ untuk semuda indikator promosi adalah lebih besar dari 0,50 dan C.R. lebih besar dari 2,00 serta nilai probabilitas ke-4 indikator tersebut lebih kecil dari 0,05 (***). Dengan demikian dapat dikatakan ditinjau dari CFA, bahwa ke-4 indikator tersebut valid sebagai indikator yang membentuk variabel laten promosi. 


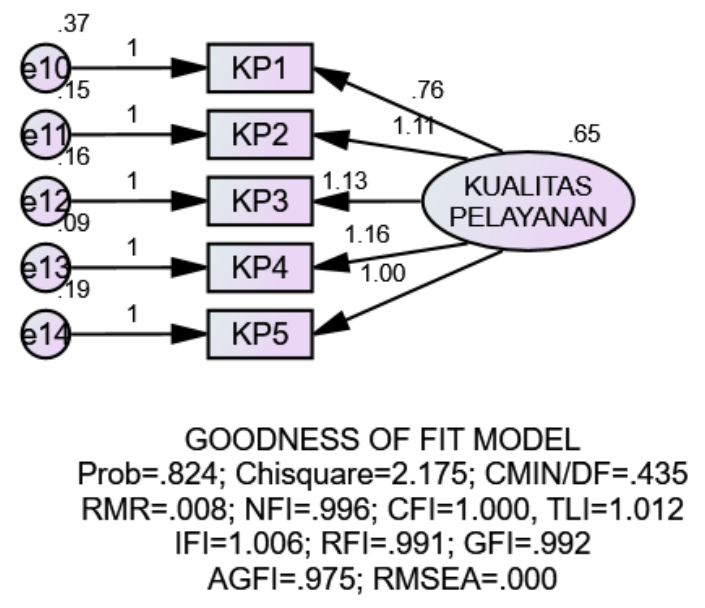

\section{Gambar 4. Analisis Faktor Konfirmatori Variabel Kualitas Pelayanan}

Sumber: Hasil Analisis Peneliti, 2020

Tabel 10.

Variabel Kualitas Pelayanan Regression Weights: (Group number 1 - Default model)

\begin{tabular}{|c|c|c|c|c|c|c|c|}
\hline & & & Estimate & S.E. & C.R. & $\mathbf{P}$ & Label \\
\hline KP5 & $<---$ & KP & 1.000 & & & & \\
\hline KP4 & $<---$ & KP & 1.158 & .076 & 15.269 & $* * *$ & par_1 \\
\hline KP3 & $<---$ & KP & 1.126 & .081 & 13.833 & $* * *$ & par_2 \\
\hline KP2 & $<---$ & KP & 1.108 & .080 & 13.936 & $* * *$ & par_3 \\
\hline KP1 & $<---$ & KP & .759 & .088 & 8.604 & $* * *$ & par 4 \\
\hline
\end{tabular}

Sumber: Data Penelitian, 2020

Tabel 11.

Squared Multiple Correlations: (Group number 1 - Default model) Variabel Kualitas Pelayanan

\begin{tabular}{lc}
\hline & Estimate \\
\hline KP1 & .502 \\
KP2 & .841 \\
KP3 & .836 \\
KP4 & .902 \\
KP5 & .777 \\
\hline \multicolumn{2}{c}{ Sumber: Data Penelitian, 2020 }
\end{tabular}

Berdasarkan tampilan analisis faktor konfirmatori terhadap indikator variabel kualitas pelayanan, baik dalam bentuk diagram maupun dalam bentuk tabel diatas, diketahui bahwa Standardized Estimate Regression Weight $(\lambda)$ untuk semuda indikator kualitas pelayanan adalah lebih besar dari 0,50 dan C.R. lebih besar dari 2,00 serta nilai probabilitas ke-5 indikator tersebut lebih kecil dari $0,05(* * *)$. Dengan demikian dapat dikatakan ditinjau dari CFA, bahwa ke-5 indikator tersebut 
valid sebagai indikator yang membentuk variabel laten kualitas pelayanan.
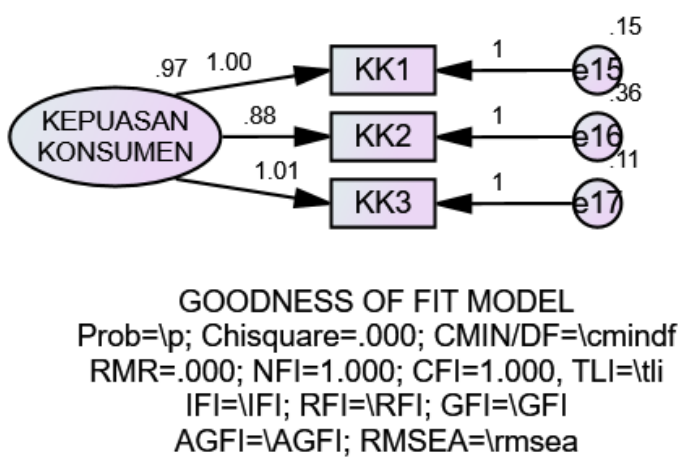

Gambar 5. Analisis Faktor Konfirmatori Variabel Kepuasan

Konsumen

Sumber: Hasil Analisis Peneliti, 2020

Tabel 12.

Variabel Kepuasan Konsumen

Regression Weights: (Group number 1 - Default model)

\begin{tabular}{lllrrrrl}
\hline & & & Estimate & S.E. & C.R. & P & Label \\
\hline KK1 & $<---$ & KK & 1.000 & & & & \\
KK2 & $<---$ & KK & .882 & .074 & 11.901 & $* * *$ & par_1 \\
KK3 & $<---$ & KK & 1.006 & .063 & 15.859 & $* * *$ & par_2 \\
\hline
\end{tabular}

Sumber: Data Penelitian, 2020

Tabel 13.

Squared Multiple Correlations: (Group number 1 - Default model) Variabel Kepuasan Pelanggan

\begin{tabular}{rr}
\hline & Estimate \\
\hline KK3 & .899 \\
KK2 & .679 \\
KK1 & .865 \\
\hline Sumber: Data Penelitian, 2020
\end{tabular}

Berdasarkan tampilan analisis faktor konfirmatori terhadap indikator variabel kualitas pelayanan, baik dalam bentuk diagram maupun dalam bentuk tabel diatas, diketahui bahwa Standardized Estimate Regression Weight $(\lambda)$ untuk semuda indikator kualitas pelayanan adalah lebih besar dari 0,50 dan C.R. lebih besar dari 2,00 serta nilai probabilitas ke-3 indikator tersebut lebih kecil dari $0,05(* * *)$. Dengan demikian dapat dikatakan ditinjau dari CFA, bahwa ke-3 indikator tersebut valid sebagai indikator yang membentuk variabel laten kualitas pelayanan. 


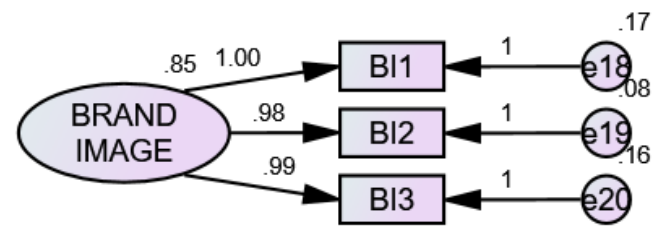

$$
\begin{gathered}
\text { GOODNESS OF FIT MODEL } \\
\text { Prob=Ip; Chisquare=.000; CMIN/DF=Icmindf } \\
\text { RMR=.000; NFI=1.000; CFI=1.000, TLI=Itli } \\
\text { IFI=VIFI; RFI=IRFI; GFI=IGFI } \\
\text { AGFI=IAGFI; RMSEA=Irmsea }
\end{gathered}
$$

\section{Gambar 6. Analisis Faktor Konfirmatori Variabel Brand Image}

Sumber: Hasil Analisis Peneliti, 2020

Tabel 14.

Variabel Brand Image

Regression Weights: (Group number 1 - Default model)

\begin{tabular}{llrrrrrr}
\hline & & & Estimate & S.E. & C.R. & P & Label \\
\hline BI1 & $<---$ & BI & 1.000 & & & & \\
BI2 & $<---$ & BI & .975 & .058 & 16.879 & $* * *$ & par_1 \\
BI3 & $<---$ & BI & .990 & .065 & 15.229 & $* * *$ & par_2 \\
\hline
\end{tabular}

Sumber: Data Penelitian, 2020

Tabel 15.

Squared Multiple Correlations: (Group number 1 - Default model) Variabel Brand Image

\begin{tabular}{cc}
\hline & Estimate \\
\hline BI3 & .839 \\
BI2 & .915 \\
BI1 & .834 \\
\hline
\end{tabular}

Sumber: Data Penelitian, 2020

Berdasarkan tampilan analisis faktor konfirmatori terhadap indikator variabel brand image, baik dalam bentuk diagram maupun dalam bentuk tabel diatas, diketahui bahwa Standardized Estimate Regression Weight $(\lambda)$ untuk semuda indikator brand image adalah lebih besar dari 0,50 dan C.R. lebih besar dari 2,00 serta nilai probabilitas ke-3 indikator tersebut lebih kecil dari 0,05 $(* * *)$. Dengan demikian dapat dikatakan ditinjau dari CFA, bahwa ke-3 indikator tersebut valid sebagai indikator yang membentuk variabel laten brand image. Dari hasil analisis normalitas dan CFA untuk setiap variabel laten di atas, maka dapat diketahui bahwa semua indikator variabel layak untuk diikutkan pada analisis lanjut.

Sesuai dengan tujuan penelitian untuk mengetahui pengaruh harga, promosi, kualitas pelayanan, kepuasan konsumen dan brand image dan hipotesis, maka analisis data dilakukan dengan menggunakan Model Persamaan Struktural 
(Structural Equation Modelling = SEM) yang merupakan sekumpulan Teknik statistik yang memungkinkan dilakukannya pengujian serangkaian hubungan yang relatif rumit secara simultan (Ferdinand, 2014; Solimun, 2012). Adapun hipotesis yang diuji adalah:

$\mathrm{H}_{1}$ : Semakin sesuai harga maka semakin baik brand image perusahaan Grab

$\mathrm{H}_{2}$ : Semakin baik promosi maka semakin baik brand image perusahaan Grab

$\mathrm{H}_{3}$ : Semakin baik kualitas pelayanan maka semakin baik brand image perusahaan Grab

$\mathrm{H}_{4}$ : Semakin baik harga maka semakin baik kepuasan konsumen pengguna Grab

$\mathrm{H}_{5}$ : Semakin baik pormosi maka semakin baik kepuasan konsumen pengguna Grab

$\mathrm{H}_{6}$ : Semakin baik kualitas pelayanan maka semakin baik kepuasan konsumen pengguna Grab

$\mathrm{H}_{7}$ : Semakin baik kepuasan konsumen maka semakin baik brand image pengguna Grab

Jumlah indikator masing-masing variabel laten adalah 5 indikator untuk variabel harga, 4 indikator untuk variabel promosi, 5 indikator untuk variabel kualitas pelayanan, 3 indikator untuk variabel kepuasan konsumen, dan 3 indikator untuk variabel brand image. Skor jawaban responden diolah dengan statistic Full Model Structural Equation Modelling (SEM) menggunakan software AMOS for windows versi 24 hingga diperoleh tampilan grafik dan hasil Regression Weight. Dari hasil pengolahan data dilakukan analisis Full Model Structural Equation Modelling (SEM).

Pengujian parameter yang dilakukan adalah pengujian parameter lamda $(\lambda \mathrm{i})$. Pengujian ini ditujukan untuk mengetahui validitas setiap indikator penelitian. Untuk pengujian parameter lamda digunakan nilai standardized estimate(regression weight) berupa loading faktor seperti tabel 16. apabila nilai lamda $(\lambda \mathrm{i})>0,50, \mathrm{CR}>\mathrm{t}_{\text {tabel }}=2,000$, dan probability $<\alpha=0,05$, maka loading faktor parameter lamda $(\lambda \mathrm{i})$ indikator tersebut dinyatakan signifikan (Ferdinand, 2014). Hal ini berarti, data indikator tersebut valid dengan variabel laten yang bersesuaian. Untuk keperluan tersebut ditampilkan tabel 16 berikut yang memuat loading faktor/ lamda $(\lambda \mathrm{i}), \mathrm{CR}$, probability $(\mathrm{P})$. Sedangkan besarnya $\alpha$ diambil $5 \%$ $=0,05$ dan $T_{\text {tabel }}=1,667$.

Tabel 16.

Regression Weight (Lamda) Indikator Harga, Promosi Dan Kualitas Pelayanan Terhadap Brand Image Grab Dengan Kepuasan Konsumen

\begin{tabular}{lllrrrrc}
\hline & & & Estimate & S.E. & C.R. & P & Ket \\
\hline HG5 & $<---$ & HG & 1.000 & & & & Valid \\
HG4 & $<---$ & HG & 1.237 & .129 & 9.622 & $* * *$ & Valid \\
HG3 & $<---$ & HG & 1.084 & .125 & 8.662 & $* * *$ & Valid \\
HG2 & $<---$ & HG & 1.298 & .131 & 9.925 & $* * *$ & Valid \\
HG1 & $<---$ & HG & .955 & .119 & 8.011 & $* * *$ & Valid \\
PRO4 & $<---$ & PRO & 1.000 & & & & Valid \\
\hline Bersambung... & & & & & & &
\end{tabular}




\begin{tabular}{|c|c|c|c|c|c|c|c|}
\hline \multicolumn{2}{|c|}{ Estimate } & \multirow{2}{*}{$\begin{array}{l}\text { S.E. } \\
\text { PRO }\end{array}$} & \multicolumn{2}{|l|}{ C.R. } & \multirow{2}{*}{$\begin{array}{c}\mathbf{P} \\
10.705\end{array}$} & \multicolumn{2}{|c|}{ Ket } \\
\hline PRO3 & $<---$ & & .816 & .076 & & $* * *$ & Valid \\
\hline PRO2 & $<--$ & PRO & .987 & .059 & 16.770 & $* * *$ & Valid \\
\hline PRO1 & $<--$ & PRO & .950 & .060 & 15.707 & $* * *$ & Valid \\
\hline KP5 & $<--$ & KP & 1.000 & & & & Valid \\
\hline KP4 & $<--$ & KP & 1.153 & .076 & 15.097 & $* * *$ & Valid \\
\hline KP3 & $<--$ & $\mathrm{KP}$ & 1.130 & .081 & 13.920 & $* * *$ & Valid \\
\hline KP2 & $<---$ & $\mathrm{KP}$ & 1.109 & .080 & 13.937 & $* * *$ & Valid \\
\hline KP1 & $<---$ & $\mathrm{KP}$ & .772 & .088 & 8.816 & $* * *$ & Valid \\
\hline KK1 & $<---$ & KK & 1.000 & & & & Valid \\
\hline KK2 & $<--$ & KK & .891 & .073 & 12.154 & $* * *$ & Valid \\
\hline KK3 & $<---$ & KK & 1.010 & .058 & 17.303 & $* * *$ & Valid \\
\hline BI1 & $<--$ & BI & 1.000 & & & & Valid \\
\hline BI2 & $<--$ & BI & .954 & .055 & 17.368 & $* * *$ & Valid \\
\hline BI3 & $<--$ & BI & .985 & .062 & 15.852 & $* * *$ & Valid \\
\hline
\end{tabular}

Sumber: Data Penelitian, 2020

Dari tabel diatas, dapat dilihat bahwa tidak ada indikator yang memiliki standardized estimate (regression weight) berupa loading faktor atau lamda $(\lambda)<$ 0,5 . Semua indikator memiliki nilai $\mathrm{CR}>2,00$ dan probability $<0,05$ serta memiliki probabilitas lebih kecil dari 0,05 (***). Dengan demikian dapat dikatakan bahwa semua indikator adalah valid.

Tabel 17.

Evaluasi Goodness of Fit

\begin{tabular}{lccc}
\hline \multicolumn{1}{c}{ Goodness Of Fit Index } & Cut-of Value & Hasil Model & Keterangan \\
\hline Chi-square $\left(\chi^{2}\right)$ & Diharapkan kecil & $\left.141,312^{*}\right)$ & Baik \\
Relative Chi-square $\left(\chi^{2} / \mathrm{df}\right)$ & $\leq 3,00$ & 0,883 & Kurang Baik \\
Probability & $>0,05$ & $\left.0,853^{*}\right)$ & Baik \\
RMSEA & $\leq 0,08$ & 0,000 & Baik \\
GFI & $\geq 0,90$ & $0,887^{+}$ & Marginal \\
AGFI & $\geq 0,90$ & $0,856^{+}$ & Marginal \\
CFI & $\geq 0,95$ & $\left.1,000^{*}\right)$ & Baik \\
TLI & $\geq 0,95$ & $1,011^{*}$ & Baik \\
\hline
\end{tabular}

*) Memenuhi Goodness of Fit

+) Marginal

Sumber: Data Penelitian, 2020

Memerhatikan nilai cut-of-value dan goodness of fit hasil model pada Tabel 17 diatas, terlihat empat kriteria yang terpenuhi dari delapan kriteria yang dipakai. Kriteria yang terpenuhi adalah Chi-square $\left(\chi^{2}\right)$, Probability, RMSEA, CFI, dan TLI dan 2 Marginal yaitu GFI dan AGFI. Karena sudah lebih dari dua kriteria dari delapan kriteria yang disyaratkan yang memenuhi syarat, maka model di atas dinyatakan sudah baik.

Persamaan structural harga, promosi, kualitas pelayanan, kepuasan konsumen dan brand image seperti persamaan berikut: 


$$
\begin{aligned}
& \mathrm{Y} 2=\gamma_{\mathrm{Y} 2 . \mathrm{x} 1} \mathrm{X}_{1}+\xi_{2}, \rightarrow \text { pengaruh langsung (Direct Effects) } \mathrm{X}_{1} \text { terhadap } \mathrm{Y} 2 \\
& \mathrm{Y} 2=\gamma_{\mathrm{Y} 2 \times 2} \mathrm{X}_{2}+\xi_{2}, \rightarrow \text { pengaruh langsung (Direct Effects) } \mathrm{X}_{2} \text { terhadap } \mathrm{Y} 2 \\
& \mathrm{Y} 2=\gamma_{\mathrm{Y} 2 \times 3} \mathrm{X}_{1}+\xi_{1}, \rightarrow \text { pengaruh langsung (Direct Effects) } \mathrm{X}_{2} \text { terhadap } \mathrm{Y} 2 \\
& \mathrm{Y} 2=\gamma_{\mathrm{y} 1 . \mathrm{x} 1} \mathrm{X}_{1}+\xi_{1}, \rightarrow \text { pengaruh tidak langsung (Indirect Effects) } \mathrm{X}_{1} \\
& \text { terhadap Y2 melalui Y1 } \\
& \mathrm{Y} 2=\gamma_{\mathrm{y} 1 . \mathrm{x} 2} \mathrm{X}_{2}+\xi_{1}, \rightarrow \text { pengaruh tidak langsung (Indirect Effects) } \mathrm{X}_{2} \\
& \text { terhadap Y2 melalui Y1 } \\
& \mathrm{Y} 2=\gamma_{\mathrm{y} 1 . \mathrm{x} 3} \mathrm{X}_{3}+\xi_{1}, \rightarrow \text { pengaruh tidak langsung (Indirect Effects) } \mathrm{X}_{3} \\
& \text { terhadap Y2 melalui Y1 } \\
& \mathrm{Y} 2=\gamma_{\mathrm{y} 2 . \mathrm{Y} 1} \mathrm{Y}+\xi_{2}, \rightarrow \text { pengaruh langsung (Direct Effects) } \mathrm{Y} 1 \text { terhadap } \mathrm{Y} 2
\end{aligned}
$$

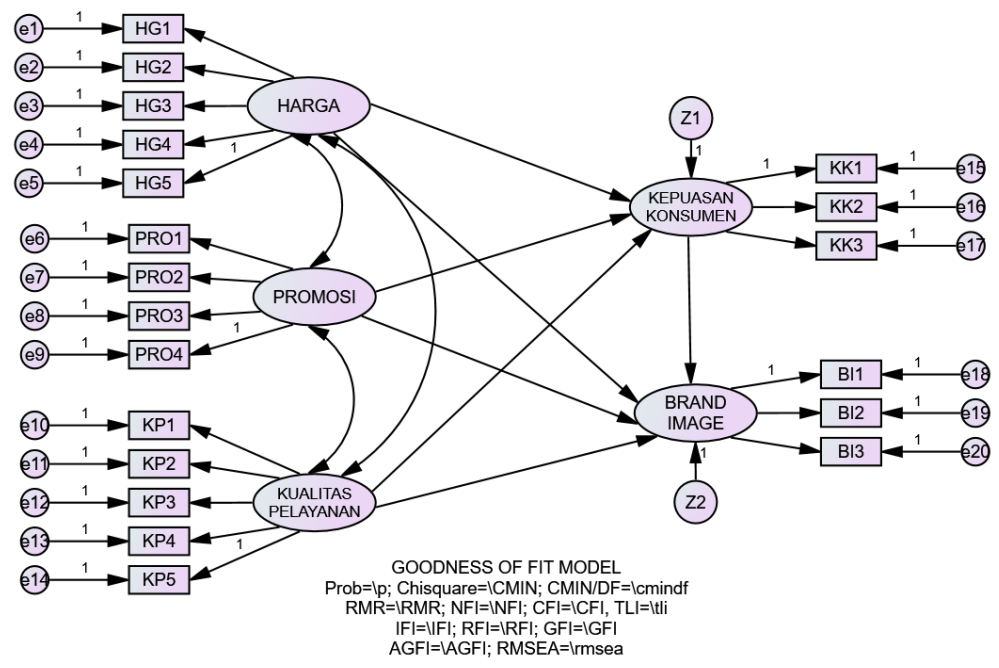

Gambar 7. Hubungan Antarvariabel

Sumber: Hasil Analisis Peneliti, 2020

Mengacu pada gambar di atas, terlihat jumlah indikator masing-masing variabel laten adalah 5 indikator untuk variabel harga, 4 indikator untuk variabel promosi, 5 indikator untuk variabel kualitas pelayanan, 3 indikator untuk variabel kepuasan konsumen, dan 3 indikator untuk variabel brand image. Skor jawaban responden diolah dengan statistic Full Model Structural Equation Modelling (SEM) menggunakan software AMOS for windows versi 24 hingga diperoleh tampilan grafik dan hasil Regression Weight. Berdasarkan gambar di atas dapat dilakukan analisis model Pengukuran dengan parameter lamda untuk pengaruh harga, promosi, kualitas pelayanan, kepuasan konsumen dan brand image, analisis goodness of fit, analisis determinasi, dan analisis model struktural.

Pengujian model dilakukan menggunakan koefisien regresi untuk variabel Harga (X1), Promosi (X2), Kualitas Pelayanan (X3), Kepuasan Konsumen (Y1), Brand Image (Y2) dan melalui tabel output dari sub menu view/set. Berdasarkan hasil perhitungan koefisien regresi (regression weight), dapat dibuat tabel output seperti disajikan pada tabel 18 berikut. 
Tabel 18.

Regression Weight Harga, Promosi, Kualitas Pelayanan, Kepuasan

Konsumen dan Brand Image

Regression Weights: (Group number 1 - Default model)

\begin{tabular}{lllrrrrr}
\hline & & & Estimate & S.E. & C.R. & P & Ket \\
\hline KK & $<---$ & HG & .425 & .128 & 3.327 & $* * *$ & Valid \\
KK & $<---$ & PRO & .316 & .111 & 2.836 & .005 & Valid \\
KK & $<---$ & KP & .320 & .122 & 2.611 & .009 & Valid \\
BI & $<---$ & KK & .382 & .096 & 3.980 & $* * *$ & Valid \\
BI & $<---$ & HG & .207 & .105 & 1.983 & .047 & Valid \\
BI & $<---$ & PRO & .237 & .091 & 2.592 & .010 & Valid \\
BI & $<---$ & KP & .222 & .099 & 2.245 & .025 & Valid \\
\hline
\end{tabular}

Sumber: Data Penelitian, 2020

Tabel 19.

Standardized Indirect Effects (Group number 1 - Default model)

\begin{tabular}{lrrrrr}
\hline & KP & PRO & HG & KK & BI \\
\hline KK & .000 & .000 & .000 & .000 & .000 \\
BI & .106 & .119 & .140 & .000 & .000 \\
\hline
\end{tabular}

Sumber: Data Penelitian, 2020 berikut:

Berdasarkan data pada Tabel 18. dan Tabel 19. dapat dijelaskan sebagai

Pengaruh variabel harga (X1) terhadap brand image (Y2) memiliki standardized estimate (regression weight) sebesar 0,207, dengan CR (Critical Ratio $=$ identic dengan t-hitung) sebesar 1,983 pada probability 0,047. Nilai CR 1,983> 1,660 dan probability $* * *<0,05$ menunjukkan bahwa pengaruh variabel harga terhadap brand image adalah signifikan. Pengaruh variabel promosi (X2) terhadap brand image (Y2) memiliki standardized estimate (regression weight) sebesar 0,237, dengan CR (Critical Ratio = identic dengan t-hitung) sebesar 2,592 pada probability 0,010 . Nilai CR 2,592 $>1,660$ dan probability $* * *<0,05$ menunjukkan bahwa pengaruh variabel promosi terhadap brand image adalah signifikan. Pengaruh variabel kualitas pelayanan (X3) terhadap brand image (Y2) memiliki standardized estimate (regression weight) sebesar 0,222 dengan CR (Critical Ratio $=$ identic dengan t-hitung) sebesar 2,245 pada probability 0,025 . Nilai CR 2,245> 1,660 dan probability $* * *<0,05$ menunjukkan bahwa pengaruh variabel kualitas pelayanan terhadap brand image adalah signifikan. Pengaruh variabel harga (X1) terhadap brand image (Y2) melalui kepuasan konsumen memiliki standardized estimate (regression weight) sebesar 0,425, dengan CR (Critical Ratio $=$ identic dengan t-hitung) sebesar 3,327 pada probability ***. Nilai CR 3,327 $>1,660$ dan probability $* * *<0,05$ menunjukkan bahwa pengaruh variabel harga terhadap brand image melalui kepuasan konsumen adalah signifikan.

Pengaruh variabel promosi (X2) terhadap brand image (Y2) melalui kepuasan konsumen memiliki standardized estimate (regression weight) sebesar 0,316, dengan CR (Critical Ratio = identic dengan t-hitung) sebesar 2,836 pada probability 0,005 . Nilai CR 2,836 $>1,660$ dan probability $* * *<0,05$ menunjukkan bahwa pengaruh variabel promosi terhadap brand image melalui kepuasan 
konsumen adalah signifikan. Pengaruh variabel kualitas pelayanan (X3) terhadap brand image (Y2) melalui kepuasan konsumen memiliki standardized estimate (regression weight) sebesar 0,320, dengan CR (Critical Ratio = identic dengan thitung) sebesar 2,611 pada probability 0,009. Nilai CR 2,2611 > 1,660 dan probability $* * *<0,05$ menunjukkan bahwa pengaruh variabel kualitas pelayanan terhadap brand image melalui kepuasan konsumen adalah signifikan. Pengaruh variabel kepusan konsumen (Y1) terhadap brand image (Y2) memiliki standardized estimate (regression weight) sebesar 0,382 dengan CR (Critical Ratio $=$ identic dengan t-hitung) sebesar 3,980 pada probability ***. Nilai CR 3,980 > 1,660 dan probability $* * *<0,05$ menunjukkan bahwa pengaruh variabel kepuasan konsumen terhadap brand image adalah signifikan.

Memperhatikan standardized estimate dan koefisien standardized direct effects untuk variabel Harga (X1), Promosi (X2), Kualitas Pelayanan (X3), Kepuasan Konsumen (Y1), Brand Image (Y2) maka dapat dibuat model persamaan structural sebagai berikut:

$$
\begin{aligned}
\mathrm{Y} 1 & =\gamma_{\mathrm{Y} 1 . x 1} \mathrm{X}_{1}+\xi_{2},=0,105 \mathrm{X}_{1}+\xi_{2} \\
\mathrm{Y} 2 & =\gamma_{\mathrm{Y} 2 . \mathrm{x} 2} \mathrm{X}_{2}+\xi_{2},=0,091 \mathrm{X}_{2}+\xi_{2} \\
\mathrm{Y} 2 & =\gamma_{\mathrm{Y} 2 . \mathrm{x} 3} \mathrm{X}_{3}+\xi_{1},=0,099 \mathrm{X}_{\mathrm{x}}+\xi_{1} \\
\mathrm{Y} 1 & =\gamma_{\mathrm{Y} 1 . \mathrm{x} 1} \mathrm{X}_{1}+\xi_{1},=0,140 \mathrm{X}_{1}+\xi_{1} \\
\mathrm{Y} 2 & =\gamma_{\mathrm{Y} 2 . \mathrm{x} 2} \mathrm{X}_{2}+\xi_{1},=0,116 \mathrm{X}_{2}+\xi_{1} \\
\mathrm{Y} 2 & =\gamma_{\mathrm{Y} 2 . \mathrm{x} 3} \mathrm{X}_{3}+\xi_{1},=0,106 \mathrm{X}_{3}+\xi_{1} \\
\mathrm{Y} 2 & =\gamma_{\mathrm{Y} 2 . \mathrm{Y} 1} \mathrm{Y}+\xi_{2},=0,096 \mathrm{Y}+\xi_{2}
\end{aligned}
$$

Berdasarkan persamaan di atas, dapat dinyatakan terdapat pengaruh positif harga terhadap brand image sebesar 0,207, terdapat pengaruh positif kualitas pelayanan terhadap brand image sebesar 0,237 , terdapat pengaruh positif kualitas pelayanan terhadap brand image sebesar 0,222 dan terdapat pengaruh positif kepuasan konsumen terhadap brand image sebesar 0,382.

Artinya bila harga (X1), promosi (X2), kualitas pelayanan (X3), kepuasan pelayanan (Y1), meningkat maka brand image (Y2) juga akan meningkat. Dan apabila sebaliknya, bila harga (X1), promosi (X2), kualitas pelayanan (X3), kepuasan pelayanan (Y1), mengalami penurunan maka brand image (Y2) akan mengalami penurunan pula. Dengan demikian hipotesis yang menyatakan :

$\mathrm{H}_{1}$ : Semakin sesuai harga maka semakin baik brand image perusahaan Grab adalah teruji benar.

$\mathrm{H}_{2}$ : Semakin baik promosi maka semakin baik brand image perusahaan Grab adalah teruji benar.

$\mathrm{H}_{3}$ : Semakin baik kualitas pelayanan maka semakin baik brand image perusahaan Grab adalah teruji benar.

$\mathrm{H}_{4}$ : Semakin baik harga maka semakin baik kepuasan konsumen pengguna Grab adalah teruji benar.

$\mathrm{H}_{5}$ : Semakin baik pormosi maka semakin baik kepuasan konsumen pengguna Grab adalah teruji benar.

$\mathrm{H}_{6}$ : Semakin baik kualitas pelayanan maka semakin baik kepuasan konsumen pengguna Grab adalah teruji benar.

$\mathrm{H}_{7}$ : Semakin baik kepuasan kosnumen maka semakin baik brand image pengguna 
Grab adalah teruji benar.

Square Multiple Correlation harga (X1), promosi (X2), kualitas pelayanan (X3) terhadap kepuasan konsumen (Y1) sebesar 0,626 dan harga (X1), promosi (X2), kualitas pelayanan (X3) dan kepuasan konsumen (Y1) terhadap brand image (Y2) sebesar 0,772 sebagaimana terlihat pada tabel 4.18 diatas. Menurut Ferdinand (2014) nilai square multiple correlation identic dengan $\mathrm{R}^{2}$ pada SPSS. Besarnya koefisien determinasi (D) adalah nilai square multiple correlation kali $100 \%=$ $0,626 \times 100 \%=62,6 \%$ dan $0,772 \times 100 \%=77,2 \%$. Dengan demikian dapat dinyatakan bahwa perubahan kepuasan konsumen (Y1) dipengaruhi oleh harga (X1), promosi (X2), kualitas pelayanan (X3) sebesar 62,6\% serta perubahan brand image (Y2) dipengaruhi oleh harga (X1), promosi (X2), kualitas pelayanan (X3) dan kepuasan konsumen (Y1) sebesar 77,2\%.

Dari seluruh analisis diatas dapat disimpulkan bahwa semua indikator untuk variabel laten valid karena memiliki $\lambda>0,50, \mathrm{CR}>2,000$ dan probability $<0,05$. Regression weight antar variabel laten adalah positif signifikan, serta hasil evaluasi goodness of fit telah memenuhi syarat yang ditentukan.

Hasil pengolahan data menunjukkan nilai standardized regression weight sebesar 0,207 serta signifikannya lebih kecil dari 0,05 (0,047). Hal ini berarti harga berpengaruh positif dan signifikan terhadap brand image. Setiap kenaikan harga satu satuan akan mampu meningkatkan brand image 0,207 satuan skor. Hasil penelitian ini menemukan arah hubungan yang konsisten dengan hipotesis pertama yang menyatakan bahwa semakin sesuai harga, makan semakin baik brand image.

Hasil penelitian ini sejalan dengan hasil penelitian yang dilakukan oleh (Billy \& Rafael, 2017) menyatakan bahwa harga berpengaruh secara signifikan terhadap brand image (Studi kasus pada transportasi berbasis online). (Suwarni, 2017) menemukan bahwa harga berpengaruh signifikan terhadap citra merek (Survei Pada Calon Konsumen Susu SGM Di Kota Malang).

Hasil pengolahan data menunjukkan nilai standardized regression weight sebesar 0,237 serta signifikannya lebih kecil dari $0,05(0,010)$. Hal ini berarti promosi berpengaruh positif dan signifikan terhadap brand image. Setiap kenaikan promosi satu satuan akan mampu meningkatkan brand image 0,237 satuan skor. Hasil penelitian ini menemukan arah hubungan yang konsisten dengan hipotesis kedua yang menyatakan bahwa semakin baik promosi, maka semakin baik brand image.

Hasil penelitian ini sejalan dengan hasil penelitian yang dilakukan oleh (Laksono \& Magnadi, 2019) menyatakan bahwa promosi berpengaruh positif dan signifikan terhadap citra merek sepatu olahraga adidas di kota Semarang. (Adiputra \& Magnadi, 2018) menemukan bahwa promosi berpengaruh positif dan signifikan terhadap citra merek Sepatu Nike. Sedangkan (Simanjuntak \& Ardani, 2018) mendapatkan hasil bahwa promosi memiliki pengaruh yang positif dan signifikan terhadap brand image jasa transportasi Uber Taksi di Kota Denpasar.

Hasil pengolahan data menunjukkan bahwa nilai bobot regresi standar adalah 0,222 , dan signifikansi lebih kecil dari $0,05(0,025)$. Artinya kualitas pelayanan berpengaruh positif dan signifikan terhadap citra merek. Setiap peningkatan kualitas pelayanan sebesar 1 unit dapat meningkatkan citra merek sebesar 0,222 unit penilaian. Hasil penelitian ini menemukan bahwa arah hubungan ini sesuai 
dengan hipotesis ketiga yang menyatakan bahwa semakin baik kualitas pelayanan maka citra merek semakin baik..

Hal tersebut sejalan dengan hasil penelitian yang dilakukan oleh (Rizan \& Rahmi, 2015) menyatakan bahwa kualitas pelayanan berpengaruh positif dan signifikan terhadap citra merek pengguna aplikasi layanan Gojek di Universitas Negeri Jakarta diterima. (Putri, A. K, Hendrayani \& Uljanatunnisa, 2020) menjelaskan jika terdapat pengaruh yang signifikan antara kualiatas pelayanan terhadap citra perusahaan Ninja Xpress. (Sari, 2019) juga menemukan bahwa kualitas layanan berpengaruh positif dan signifikan terhadap citra merek (studi pada pelanggan majelis mie cabang citarum, surabaya).

Dari hasil analisis jalur menunjukkan nilai koefisien standardized regression weight sebesar 0,425 serta signifikannya lebih kecil dari 0,05 (***). Hal ini berarti harga berpengaruh positif dan signifikan terhadap brand image dengan kepuasan konsumen sebagai variabel intervening. Setiap kenaikan harga satu satuan akan mampu meningkatkan kepuasan konsumen sebesar 0,425 satuan skor. Hasil penelitian ini menemukan arah hubungan yang konsisten dengan hipotesis keempat yang menyatakan bahwa semakin sesuai harga, maka semakin baik kepuasan konsumen.

Hasil penelitian ini sejalan dengan hasil penelitian yang dilakukan oleh (Anggriana, 2017) menyatakan bahwa harga mempunyai pengaruh positif signifikan terhadap kepuasan pelanggan jasa ojek online "Om-Jek" Jember. (Purnamasari, 2015) menemukan bahwa harga berpengaruh positif dan signifikan terhadap kepuasan konsumen produk M2 Fashion Online di Singaraja Tahun 2015. (Handoko, 2019) juga menemukan adanya pengaruh yang signifikan harga terhadap kepuasan konsumen di JNE.

Dari hasil analisis jalur menunjukkan nilai koefisien standardized regression weight sebesar 0,316 serta signifikannya lebih kecil dari $0,05(0,005)$. Hal ini berarti promosi berpengaruh positif dan signifikan terhadap brand image dengan kepuasan konsumen sebagai variabel intervening. Setiap kenaikan promosi satu satuan akan mampu meningkatkan kepuasan konsumen sebesar 0,316 satuan skor. Hasil penelitian ini menemukan arah hubungan yang konsisten dengan hipotesis kelima yang menyatakan bahwa semakin baik promosi, maka semakin baik kepuasan konsumen.

Hasil penelitian ini sejalan dengan hasil penelitian yang dilakukan oleh (Anggriana, 2017) menyatakan bahwa promosi berpengaruh positif dan signifikan terhadap kepuasan pelanggan jasa ojek online "Om-Jek" Jember. (Handoko, 2019) menemukan adanya pengaruh yang signifikan promosi terhadap kepuasan konsumen di PT Maxim Houseware Indonesia Medan. (Fiona, 2020) menjelaskan bahwa sales promotion memiliki hubungan, pengaruh positif dan signifikan terhadap kepuasan konsumen (Studi pada pelanggan Gopay di Jabodetabek).

Dari hasil analisis jalur menunjukkan nilai koefisien standardized regression weight sebesar 0,320 serta signifikannya lebih kecil dari $0,05(0,009)$. Hal ini berarti kualitas pelayanan berpengaruh positif dan signifikan terhadap brand image dengan kepuasan konsumen sebagai variabel intervening. Setiap kenaikan kealitas pelayanan satu satuan akan mampu meningkatkan kepuasan konsumen sebesar 0,320 satuan skor. Hasil penelitian ini menemukan arah hubungan yang konsisten 
dengan hipotesis keenam yang menyatakan bahwa semakin baik kualitas pelayanan, maka semakin baik kepuasan konsumen.

Hasil penelitian ini sejalan dengan hasil penelitian yang dilakukan oleh (Anggriana, 2017) menyatakan bahwa adanya pengaruh positif signifikan kualitas layanan terhadap kepuasan pelanggan jasa ojek online "Om-Jek" Jember. (Handoko, 2019) menemukan terdapat pengaruh yang signifikan kualitas pelayanan terhadap Kepuasan konsumen di PT Maxim Houseware Indonesia Medan. (Melda $\&$ Gede, 2020) juga menemukan bahwa kualitas pelayanan berpengaruh positif terhadap kepuasan pelanggan pengguna jaringan 4G di Denpasar.

Dari hasil analisis jalur menunjukkan nilai koefisien standardized regression weight sebesar 0,382 serta signifikannya lebih kecil dari $0,05(* * *)$. Hal ini berarti kepuasan konsumen berpengaruh positif dan signifikan terhadap brand image. Setiap kenaikan kepuasan konsumen satu satuan akan mampu meningkatkan brand image sebesar 0,382 satuan skor. Hasil penelitian ini menemukan arah hubungan yang konsisten dengan hipotesis ketujuh yang menyatakan bahwa semakin baik kepuasan konsumen, maka semakin baik brand image.

Kepuasan konsumen berarti konsumen dapat menikmati layanan dari perusahaan seperti produk atau jasa yang diberikan kepada konsumen. Semakin baik produk atau layanan yang diberikan oleh perusahaan maka konsumen akan merasa puas. Begitu juga sebaliknya, semakin buruk produk atau layanan yang diberikan oleh perusahaan maka konsumen akan merasa tidak puas. Brand Image akan timbul apabila konsumen telah mencoba atau mencari infomasi mengenai produk atau layanan dari perusahaan.

\section{SIMPULAN}

Berdasarkan hasil analisis dan pembahasan diatas, maka dapat disimpulkan bahwa; (1) harga memiliki pengaruh yang positif dan signifikan terhadap brand image, (2) promosi memiliki pengaruh yang positif dan signifikan terhadap brand image, (3) kualitas pelayanan memiliki pengaruh yang positif dan signifikan terhadap brand image, (4) harga berpengaruh positif dan signifikan terhadap brand image dengan kepuasan konsumen sebagai variabel intervening, (5) promosi berpengaruh positif dan signifikan terhadap brand image dengan kepuasan konsumen sebagai variabel intervening, (6) kualitas pelayanan berpengaruh positif dan signifikan terhadap brand image dengan kepuasan konsumen sebagai variabel intervening, dan (7) kepuasan konsumen memiliki pengaruh yang positif dan signifikan terhadap brand image.

\section{REFERENSI}

Adiputra, N., \& Magnadi, R. H. (2018). Analisis Pengaruh Desain Produk, Perceived Value, Dan Promosi Terhadap Citra Merek Sepatu Nike (Studi Pada Konsumen Sepatu Nike Di Kota Semarang). Diponegoro Journal of Management.

Anggriana, R. et al. (2017). Pengaruh Harga, Promosi, Kualitas Layanan Terhadap Kepuasan Pelanggan Jasa Ojek Online "Om-Jek" Jember. Jurnal Sains 
Manajemen Dan Bisnis Indonesia.

Assauri, S. (2014). Manajemen Produksi dan Operasi. LPFEUI.

Billy, L., \& Rafael, H. (2017). Pengaruh Harga Dan Promosi Grab Terhadap Brand Image yang Mempengaruhi Keputusan Pembelian Konsumen Pengguna Transportasi Berbasis Online. Jurnal Riset Manajemen Dan Bisnis (JRMB).

Cahyu. (2019). Kisah Perjalanan Grab dari Lahir Hingga Jadi Decacorn. Liputan 6. https://www.liputan6.com/tekno/read/3912922/kisah-perjalanan-grab-darilahir-hingga-jadi-decacorn

Christina, S., \& Fransisca. (2014). Pengaruh Kualitas Pelayanan Dan Citra Korporasi Terhadap Kesetiaan Pelanggan Melalui Kepuasan Pelanggan. Jurnal Manajemen Dan Pemasaran Jasa, Volume 7,.

Fiona, D. R. (2020). Pengaruh Promosi penjualan dan E-Service Quality terhadap Minat Beli Ulang Melalui Kepuasan Pelanggan (Studi pada pelanggan Gopay di Jabodetabek). Jurnal Ilmu Dan Administrasi Bisnis.

Handoko, A. (2019). Pengaruh Promosi, Harga Dan Kualitas Pelayanan Terhadap Kepuasan Konsumen Di Titipan Kilat Jne Medan. Jurnal Ilmiah Manajemen Dan Bisnis.

Kasmir. (2016). Manajemen Sumber Daya Manusia (Teori, Definisi \& Konsep). PT. Raja Grafindo Persada.

Kotler, P., \& Amstrong, G. (2012). Prinsip-Prinsip Pemasaran (13th ed.). Erlangga.

Kotler, P., \& Kevin, L. K. (2016). Marketing Management, 15th Edition. Pearson Education.

Laksono, E. B., \& Magnadi, R. H. (2019). Analisis Pengaruh Promosi, Inovasi Produk, dan Saluran Distribusi Terhadap Citra Merek Sepatu Olahraga Adidas di Kota Semarang. Diponegoro Journal Of Management.

Luo, W., \& Chung, Q. B. (2015). Retailer Reputation and Online Pricing Strategy. Journal of Computer Information Systems.

Melda, K. S., \& Gede, S. D. (2020). Faktor-Faktor Terpenting yang Mempengaruhi Kepuasan dan Loyalitas Pelanggan Pengguna Jaringan 4G di Denpasar. Jurnal Manajemen Bisnis, Volume 17,.

Putri, A. K, Hendrayani, Y., \& Uljanatunnisa. (2020). Studi Kualitas Pelayanan pada Sosial Media Instagram Ninja Xpress Terhadap Peningkatan Citra Perusahaan. Jurnal Kajian Komunikasi, Volume III.

Rizan, M. Y. D., \& Rahmi. (2015). The Influence Of Price And Service Quality Of Brand Image And Its Impact On Customer Satisfaction Gojek (Students Study On A State University Of Jakarta). Jurnal Riset Manajemen Sains Indonesia (JRMSI), Vol 6, No.

Sari, C. W. (2019). Pengaruh Rebranding Dan Kualitas Layanan Terhadap Citra Merek (Studi Pada Pelanggan Majelis Mie Cabang Citarum, Surabaya). Jurnal Ilmu Manajemen, Volume $7 \mathrm{~N}$.

Simanjuntak, E. S., \& Ardani, I. G. K. (2018). Peran Brand Image Memediasi Pengaruh Promosi Dan Harga Terhadap Loyalitas Konsumen Uber Taksi Di Denpasar. E-Jurnal Manajemen Unud, Vol. 7, No.

Sunyoto, D. (2014). Dasar-Dasar Manajemen Pemasaran. PT. Buku Seru.

Suwarni, E. (2017). Pengaruh Iklan Di Televisi, Kualitas Produk Dan Harga 
Ida Bagus Putra Pradnyana, Pengaruh Harga, Promosi...

Terhadap Citra Merek Serta Implikasinya Pada Minat Pembelian (Survei Pada Calon Konsumen Susu Sgm Di Kota Malang). Jurnal Administrasi Bisnis.

Tjiptono, F. (2014). Pemasaran Jasa - Prinsip, Penerapan, dan Penelitian. Andi Offset.

Tjiptono, F., \& Gregorius, C. (2016). Service, Quality \& Satisfaction. Andi. 